\title{
Relevansi dan Jejak Pemikiran Prof. Dr. S.M.P. Tjondronegoro dalam Pendidikan Sosiologi Pedesaan
}

\section{The Relevance and Imprint of Professor Tjondronegoro's Thoughts in Rural Sociology}

\author{
Lala M. Kolopaking ${ }^{1, *}$, Fredian Tonny ${ }^{1}$, Lukman Hakim ${ }^{1}$
}

${ }^{1}$ Departemen Sains Komunikasi dan Pengembangan Masyarakat, Institut Pertanian Bogor, Bogor 16680, Indonesia

${ }^{*}$ E-mail korespondensi: lalako@apps.ipb.ac.id

Accepted: March 19, 2021 | Revised: July 26, 2021 | Accepted: July 29, 2021 | Online publication: August 8, 2021

\section{ABSTRACT}

Rural Sociology Education in Indonesia is the "academic arena" by Late Prof. Dr. S.M.P. Tjondronegoro. This paper aims to show the academic arena of the deceased as a media for institutionalizing and developing social science, especially in the Field of Sociology and Applied Anthropology with a focus on organizing village development. With a systematic review method, document review, and interviews with selected alumni from the Postgraduate Study Program (Master and Doctor degree) of Rural Sociology (SPD), Department of Community Development Sciences, Faculty of Human Ecology, Bogor Agricultural University, it was noted that the curriculum of this study program is rooted and grew from the thoughts of the deceased. In fact, the subjects taught by the deceased with others SPD founders, namely the deceased Prof. Sajogyo and the deceased Prof. Pujiwati Sajogyo were continuously developed, until now they have become various subjects and elements of the three specialization of students from the SPD Study Program at the Master degree. The three specializations are (1) Community Development, (2) Agrarian Studies and Political Ecology, and (3) Digitalization of Villages and Social Change. The common thread of the thought of the deceased to link these three specializations is the thought of sodality which is the root of the village in managing sustainable development.

Keywords: digital community development, political ecology, rural sociology, sodality

\section{ABSTRAK}

Pendidikan Sosiologi Pedesaan di Indonesia adalah “arena-akademik” dari almarhum Prof. Dr S.M.P. Tjondronegoro. Tulisan ini bertujuan menunjukkan arena-akademik dari almarhum tersebut sebagai wadah pelembagaan dan pengembangan pemikiran sains sosial, khususnya di Bidang Sosiologi dan Antropologi Terapan dengan fokus pengorganisasian pembangunan desa. Dengan systematic review method, tinjauan atas isi dokumen, dan wawancara dengan alumni terpilih dari Program Studi (Prodi) Pascasarjana (Pendidikan Magister Sains dan Doktor) Sosiologi Pedesaan (SPD), Departemen Sains Pengembangan Masyarakat, Fakultas Ekologi Manusia, Institut Pertanian Bogor dicatat, bahwa kurikulum prodi ini, tidak lepas dari pemikiran almarhum. Bahkan, mata-mata kuliah yang diampu oleh almarhum bersama pendiri SPD lainnya, yaitu almarhum Prof. Sajogyo dan almarhum Prof. Pujiwati Sajogyo terus dikembangkan, hingga saat ini telah menjadi berbagai mata kuliah dan unsur dari tiga kompetensi peminatan mahasiswa dari Prodi SPD untuk pendidikan magister sains. Tiga peminatan tersebut adalah (1) Pengembangan Masyarakat, (2) Kajian Agraria dan Ekologi Politik, dan (3) Digitalisasi Desa dan Perubahan Sosial. Benang merah pemikiran almarhum menjadi penjalin tiga peminatan tersebut adalah pemikiran tentang sodality yang menjadi akar dari desa mengelola pembangunan secara berkelanjutan.

Kata kunci: pengembangan komunitas digital, ekologi politik, sosiologi pedesaan, sodality

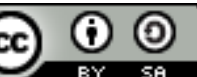

Content from this work may be used under the terms of the Creative Commons Attribution-Share A like 4.0 International. Any further distribution of this work must maintain attribution to the author(s) and the title of the work, journal citation and DOI.

Published under Department of Communication and Community Development Science, IPB University and in association with Ikatan Sosiologi Indonesia

E-ISSN: 2302-7525 | P-ISSN: 2302-7157 


\section{PENDAHULUAN}

Dalam khasanah pengembangan Ilmu-ilmu Sosial di Indonesia, Sosiologi Pedesaan yang dikembangkan oleh Institut Pertanian Bogor (IPB) memiliki ciri khas. Sejak momentum awal sampai dengan peristiwa reformasi terhadap tatanan nasional atau periode 1975-1998, Sosiologi Pedesaan di IPB dikembangkan melalui riset dan pendidikan secara bersamaan. Riset-riset dilakukan oleh Lembaga Penelitian Sosiologi Pedesaan (LPSP) yang kemudian menjadi Pusat Studi Pembangunan-Lembaga Penelitian (PSP-LP), sementara pendidikan Strata Magister (S2) dan Doktor (S3) diselenggarakan oleh Program Pascasarjana yang kemudian berkembang menjadi Fakultas dan Sekolah Pascasarjana. Pada periode ini ketika pengembangan dan pendidikan ilmu sosial umumnya masih didominasi tradisi teori modernisasi yang lebih menekankan persoalan kultur pembangunan, Sosiologi Pedesaan IPB telah dengan kritis menyuarakan persoalan struktural yang dihadapi massa rakyat serta memberikan usulan solusinya. Kala itu, pembahasan solutif yang menekankan hal-hal struktural seperti penguatan kelas sosial yang tertinggal, masih dianggap "haram"(Farid, 2014, 2017).

Sosiologi Pedesaan dikembangkan sebagai hibrid ilmu yang memuat ragam cabang ilmu-ilmu sosial, seperti Sosiologi-Antropologi (Sosial), Psikologi Sosial, Ekologi, Komunikasi. Dari segi jenis, Sosiologi Pedesaan disebut sebagai ilmu yang diterapkan (Applied Sociology). Pendekatan pengembangan keilmuannya kuat dalam empirisme, sehingga mengenal prinsip Dari Lapangan, Berteori, dan kembali ke Praktek Lapangan yang Berteori (Sajogyo, 2004). Pendekatan ini terus berkembang hingga saat ini, sebagai sebuah sistem.

Dalam konteks berteori dan membangun praktek yang berteori dalam pengembangan Sosiologi Pedesaan ini, almarhum Prof. Dr. S.M.P Tjondronegoro mempunyai peranan besar. Penguatan pengetahuan tentang Teori-teori Klasik, Modern (Aliran-aliran utama), hingga Kerangka Integratif Dunia/Global dari Sosiologi diberikan almarhum dalam pengajaran, yang bersamaan dengan memberi ulasan berbagai perspektif ekonomi tentang petani (peasant yang berciri berbeda dibanding usahawan pertanian/farmer). Almarhum juga menanamkan kerangka teoritik berkenaan dengan perubahan sosial dari skala mikro desa hingga makro global, dan pentingnya pengembangan memperhatikan industrialisasi hingga ekologi manusia (Tjondronegoro, 1979, 1986a, 1990, 1996, 2005).

Tulisan ini bermaksud memperlihatkan jejak pemikiran Prof. Dr. S.M.P Tjondronegoro dalam kurikulum pendidikan Sosiologi Pedesaan sejak Tahun 1975 hingga pengembangan pemikiran beliau pada kurikulum yang disusun pada Tahun 2020/2021. Sasaran yang diupayakan dicapai dalam hal ini adalah teridentifikasikan pemikiran Prof. Dr. S.M.P Tjondronegoro yang berkembang dan dikembangkan sebagai landasan pemikiran pendidikan Sosiologi Pedesaan di Indonesia.

\section{METODE}

Penulisan dilakukan dengan memodifikasi systematic review method (Kitchenham, 2004) dan melakukan wawancara dengan alumni terpilih dari Prodi Pascasarjana SPD di aras S2/S3, Departemen Sains Komunikasi dan Pengembangan Masyarakat, Fakultas Ekologi Manusia, Sekolah Pascasarjana Institut Pertanian Bogor. Melalui metode tersebut, tulisan ini disiapkan dapat menjadi satu "dokumen kebijakan" pengembangan kurikulum pendidikan Sosiologi Pedesaan di Indonesia. Perlu dicatat, Kurikulum Prodi SPD Tahun 2021 yang dibuat secara bertahap melalui seri lokakarya (lokakarya Divisi Sosiologi Pedesaan dan Pengembangan Masyarakat, lokakarya Program Studi Sosiologi Pedesaan, lokakarya Departemen Sains Komunikasi dan Pengembangan Masyarakat dan lokakarya Fakultas) dalam periode 2019 hingga 2020, dan melibatkan pihak-pihak berkepentingan (dosen, mahasiswa dan alumni, lembaga pengguna dari pemerintahan, lembaga swadaya masyarakat, dan korporasi) yang berasal dari seluruh pelosok tanah air yang kegiatannya dikomandani oleh Dr. Ekawati Sri Wahyuni sebagai Sekertaris Prodi SPD. Kemudian, semua data dan informasi dari berbagai pustaka, hasil wawancara dan lokakarya yang didapat, diolah untuk dijadikan tulisan sebagai bukti, bahwa Pemikiran Prof. Dr. S.M.P Tjondronegoro menjadi akar landasan dalam pengembangan kurikulum pendidikan Sosiologi Pedesaan paling tidak untuk periode 2021-2025. 


\section{HASIL DAN PEMBAHASAN}

\section{Sodality: Solusi Persoalan Struktural Pembangunan}

Sebelum diundangkan Undang-Undang Nomor 6 Tahun 2014 tentang Desa, maka kedudukan desa dalam struktur penyelenggaraan negara dan pembangunan adalah unit dalam hierakhi paling rendah dan sebagai obyek. Warga desa dan Desa tidak pernah dilibatkan secara sistematis dalam pengambilan keputusan yang berkenaan dengan penyelesaian kepentingan mereka. Bahkan, desa cenderung dijadikan alat pemerintah sebagai atasan dalam intervensi pemerintahan yang kuat ke warga desa (Kolopaking, L, 2014; Maschab, 2013).

Dalam situasi sebagaimana diuraikan sebelumnya, Almarhum Prof. Dr. S.M.P. Tjondronegoro menemukan fakta yang menunjukkan pentingnya sebuah unit sosial yang berdaya hidup dalam merancang pembangunan desa yang berpihak kepada warga desa. Diusulkan konsep sodality yang menjadi tesis dalam disertasi almarhum sebagai sebuah solusi menjembatani ketimpangan struktural antara desa dengan organisasi "Atas-Desa" dalam merancang dan melaksanakan pembangunan. Pemikiran seperti ini kaya akan pelacakan inovasi sosial agar desa yang berada di bawah komando kecamatan sebagai perwakilan pemerintah pusat dalam pembangunan nasional dapat keluar dari jebakan pembangunan yang meminggirkan desa tanpa perlu merusak struktur pemerintahan dan pembangunan secara keseluruhan.

Sodality diambil Bahasa Latin sodalis yang menggambarkan kesatuan masyarakat kecil yang sedikit memuat hubungan kekerabatan tetapi sudah sangat mengenal hubungan kepentingan tanpa menghilangkan hubungan primer. Konsep sodality sebagaimana digambarkan di dalam Gambar 1 . Konsep ini dibangun mulai dengan penjelasan perkembangan kontinuum dari lembaga ke organisasi akibat modernisasi gejala tradisi sosial yang dikenal lembaga berkembang menjadi berciri organisasi. Desa kemudian cenderung menjadi bagian organisasi, yang diikuti mengencer kepekatan unsur-unsur demokrasi. Berdasarkan gambar tersebut ditunjukkan, bahwa lingkungan modern (mutakhir/terkini) cenderung dicirikan kerelaan kepatuhan atas kekuasaan. Lingkungan ini berbeda dengan lingkungan sosial yang didominasi dalam orientasi pemenuhan kebutuhan hidup. Lingkungan kerelaan tunduk atas kekuasaan tersebut memiliki karakteristik organisasi dan dari mereka yang berada di lapisan atas masyarakat, dan merupakan hasil dari memudarnya ikatan patronisasi dan digantikan oleh penguatan ikatan kohesi regime (prosedur dan peraturan), serta menurunnya ikatan berbasis norma (tidak tertulis) sebagai dasar membangun kohesi sosial dan berganti karena masyarakat lebih mengalami sosialisasi menurut bidang (pekerjaan).

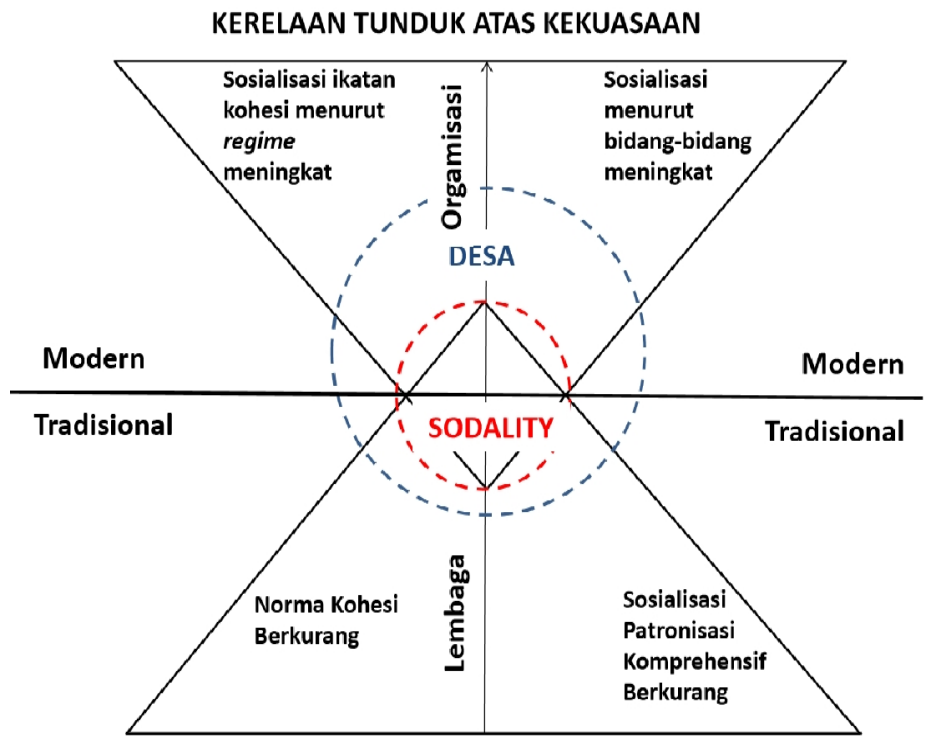

PEMENUHAN KEBUTUHAN

Gambar 1. Kerangka Pemikiran Struktur tentang Sodality Dalam Perancangan Pembangunan Desa Sumber : Modifikasi Gambar S.M.P. Tjondronegoro, 1982, dan 1984 
Dalam Gambar 1 kemudian ditunjukkan, konsep sodality berada di antara "lingkungan pemenuhan kebutuhan hidup dan lingkungan tunduk atas kekuasaan". Dalam pembangunan desa di Jawa ini berupa kesatuan masyarakat kecil yang berdaya hidup dan berada di "bawah-desa", yaitu dukuh atau kampung (Tjondronegoro, 1984). Dalam konsep komunitas, unit sosial ini dikenal sebagai komunitas yang mempunyai batas wilayah (community by place). Lihat tulisan (Kelly Hamshaw, Shoshanah Inwood, 2018) yang memberi pengertian komunitas yang mengenal batasan wilayah geografis dalam kaitan pengembangan wilayah. Oleh karena itu, dalam melakukan melacak sodality, dimasukkan pertimbangan perbedaan ekologi sebagai social change setting. Dalam konteks ini, menjadi bukti perhatian Almarhum Prof. Dr. S.M.P. Tjondronegoro terhadap ekologi manusia telah menjadi bagian dari pemikiran beliau sejak lama. Hal ini dalam perkembangan selanjutnya sejalan dengan upaya melakukan pengembangan komunitas yang sejalan dengan keberlanjutan ekosistem alam sebagaimana diulas oleh (Fontaine, 2018).

Konsep Sodality dalam era pelaksanaan Undang-Undang Nomor 6 Tahun 2014 tentang Desa masih relevan. Oleh karena, dari kajian sodality menunjukkan penetrasi pengaruh "Atas-Desa" ke Desa membuat keretakan orientasi kepentingan antara sepertiga lapisan atas dengan dua-pertiga lapisan lainnya dari warga desa. Hanya pemimpin di "aras sodality" yang masih memiliki orientasi yang sama dengan para pengikutnya. Dengan demikian, kepemimpinan dan menjaga keterlibatan pengikut dalam berpartisipasi mengelola pembangunan dengan iklim demokrasi di desa menjadi hal yang penting. Sebagaimana diketahui, peranan kepala desa atau nama lain sesuai dengan daerah, menjadi sangat kuat dalam pengaturan Undang-Undang tentang Desa tersebut. Dengan demikian, mekanisme pengelolaan pembangunan oleh desa (Desa Membangun) perlu bersamaan dengan membangun iklim agar kepala desa mengelola pembangunan dalam politik desa yang demokratis, bukan malahan meneruskan iklim pengaturan pembangunan "top-down" di aras desa (Kolopaking, L, 2014).

Keterkaitan lain yang masih relevan dalam era saat ini adalah mendorong kerjasama antar desa yang dalam Undang-Undang Nomor 6 Tahun 2014 tentang Desa diatur tentang Kawasan Pedesaan. Almarhum Prof. Dr. S.M.P Tjondronegoro sangat memberi perhatian terhadap hal ini. Pelemahan kerjasama antar desa telah berlangsung lama dan malahan mengalami pembiaran. Akibatnya, pembangunan kerjasama antar desa dalam satuan kawasan (Membangun Desa) yang dikaitkan dengan pengelolaan wilayah kecamatan cenderung dilihat sebagai tugas birokrasi dalam meyalurkan instruksiinstruksi pesan pembangunan. Pada akhirnya, satuan-satuan organisasi di desa-desa tidak mampu membangun iklim partisipatif yang cerdas menanggapi ragam ekosistem dalam cakupan tugas kecamatan sebagai bagian pemerintah daerah (Kota/Kabupaten). Lihat pembahasan kecamatan (Kolopaking, L, 2008).

Hakekat kerjasama antar desa adalah kegiatan yang membuka ruang untuk desa melakukan 4 hal. Pertama, memperbesar skala usaha secara ekonomi; kedua, menguatkan kohesi sosial agar membentuk kelompok sosial yang kuat dalam posisi-tawar berhadapan dengan kelompok sosial lain; ketiga, menjaga keberlanjutan sumberdaya alam dan lingkungan; serta keempat, adalah komunitas desa dan pemerintah desa membangun tata-kelola kerjasama multi-pihak untuk membangun secara kolaboratif (Kolopaking, L, 2017). Menurut Almarhum Prof. Dr. S.M.P Tjondronegoro, 4 hal ini dapat dikembangkan dengan mulai dari unit sosial yang mempunyai daya hidup sebagaimana konsep sodality, dan terus dikembangkan secara bertahap dengan arah baik secara horizontal maupun vertikal hingga aras "Atas Desa" (mulai dari desa, lokal, hingga nasional).

Kerjasama tersebut dikembangkan dengan multi-pihak yang berkepentingan dan dikelola bukan oleh lembaga pemerintahan, tetapi organisasi sendiri yang setidaknya dikelola dalam wilayah kecamatan. Dicatat, hal tersebut dapat dilakukan dalam upaya melacak solusi atas persoalan-persoalan agraria. Merujuk pendapat (Satria, 2021) yang berhubungan dengan hal itu adalah pentingnya tata-kelola modernisasi ekologi sebagai bagian dari perspektif Ekologi Politik. Tantangan terbesarnya dalam hal ini disebutkannya, adalah pengembangan strategi pembangunan yang bersahabat dengan peningkatan kesejahteraan masyarakat, dan keberlanjutan sumberdaya alam/lingkungan.

Tata kelola kepemerintahan dibanding penguatan birokrasi diprediksi akan terus berkembang dalam menghadapi persoalan kehidupan pada masa mendatang. Lebih lagi, dalam era perkembangan teknologi digital, hal tersebut terus berkembang. Bahkan, proses tersebut dapat menguatkan network governance sebagaimana disebut (Rhode, 2014). Dengan ciri, tata-kelola diikuti oleh governing without government. Dalam konteks kerjasama antar desa, proses tersebut sudah dapat ditemui di lapang. Tata-kelola yang berbasis teknologi digital (khususnya pemanfaatan internet dalam kerjasama antar desa) ditemukan dari 
Teladan di Kabupaten Tasikmalaya menjadi bukti solusi masalah struktural pembangunan yang diikuti penguatan budaya digital yang memuat proses dengan kecepatan, ringkas, kelincahan pelaku dan lebih efektif dan efisien (Kolopaking, L, 2020).

\section{Masyarakat Abad Digital}

Satu perhatian pokok dari Almarhum Prof. Dr. S.M.P. Tjondronegoro adalah peranan teknologi sebagai sumber tranformasi masyarakat. Lihat kembali ulasan tentang teknologi dan industrialisasi (Tjondronegoro, 1986b). Pandangan ke depan dari almarhum juga didapat ketika berdiskusi mengenai gagasan tentang Global Village dalam satu rapat Badan Pekerja Dewan Riset Nasional (DRN) yang mengundang rekan-rekan Akademi Ilmu Pengetahuan Indonesia (AIPI) pada Tahun 2013, dan almarhum hadir. Perlu dicatat, almarhum pernah menjadi anggota DRN dan juga AIPI. Satu hasil diskusi tersebut adalah keperluan menyiapkan kaitan teknologi komunikasi informasi sebagai media konektivitas masyarakat desa yang berjejaring merujuk konsep network society dari Castells (2010), dan juga sebagai penghubung utama dalam kesatuan negara Indonesia.

Dalam diskusi ketika itu yang disebutkan di atas, belum terbayang kecepatan perkembangan konektivitas melalui penetrasi internet di Indonesia. Ternyata, data pada Tahun 2020 ditunjukkan, bahwa dari 272,1 juta penduduk Indonesia yang mengakses internet telah mencapai 175,4 juta atau 64 persen. Bahkan, penduduk yang mempunyai konektivitas melalui handphone sudah 338,2 juta penduduk atau 124 persen dari jumlah penduduk. (Inet.detik.com, 2020) Hal yang kemudian perlu dicatat, bahwa pada Tahun 2017, terbit satu buku dengan judul provokatif : Society Now Becoming Digital dari Mosco (2017). Isi buku ini mengingatkan dunia sedang bergerak membentuk masyarakat yang merupakan kelanjutan dari pengaruh internet. Ia mengemukakan, bukan hanya internet tetapi juga teknologi yang lain masuk dan kemudian melekat pada kekuasaan, politik dan menentukan ekonomi-politik, serta pola kebudayaan sebagian besar dari penduduk dunia. Lihat juga bahasan teknologi digital selain internet dalam kaitan Teknologi 4.0 sebagai penggerak Revolusi Industri 4.0, misal kecerdasan buatan, manajemen data besar. (Schwab, 2016) Kehidupan digital (life is digital) semakin dekat dengan keseharian. Tidak keliru, apabila Deborah Lupton (2015) berpendapat, bahwa Sosiologi perlu mengulas dan menteorikan masyarakat dalam memasuki abad digital ini.

Pemikiran yang peduli melihat persoalan struktural sebagaimana Almarhum Prof. Dr. S.M.P. Tjondronegoro, menjadi penting dalam kaitan perkembangan masyarakat digital. Merujuk pemikiran (Prior, 2013) sudah mengulas hal tersebut, dengan menguraikan dimensi struktur adalah satu dari empat unsur lain dari telaah Sosiologi Digital (lainnya adalah Relasi Sosial dengan dasar konektivitas, Ruang Sosial, Mediasi antar kelompok dan Praktek Sosial). Dalam hal ini, persoalan struktural dalam masyarakat era digital yang perlu ditelaah dan dicarikan solusinya, adalah seperti persoalan digital divide (kesenjangan akses teknologi digital antar lapisan masyarakat atau antar lokasi tinggal) atau digital inequality (kesenjangan dampak manfaat antar lapisan masyarakat dari teknologi digital), atau masalah ketidaksetaraan gender dalam perkembangan dan pengembangan teknologi digital (Jan A.G.M.van Dijk, 2013; Singleton, 2013).

Sodality sebagaimana disebut sebelumnya dapat disebut sebagai komunitas berbasis lokasi geografis. Dalam era digital, komunitas yang akan berkembang adalah yang berbasis kepentingan dengan dasar konektivitas antar individu. Hal ini sudah diingat sosiolog yang menekuni masyarakat digital, bahwa Konsep-konsep Dasar Sosiologi akan mengalami modifikasi, atau malahan memerlukan teoritisasi baru. Sebuah langkah yang pada akhirnya akan berimpilikasi terhadap pemikiran ulang tentang data dan penelitian sebagai dasar pengembangan ilmu (Deborah Lupton, 2015). Keperluan tentang pemikiran ulang konsep-konsep dasar tersebut disuarakan juga oleh beberapa orang, seperti (Beer, 2013; Evans, 2013). Implikasi dari hal tersebut, memberi perhatian pada warga desa sebagai subyek menjalani digitalisasi yang semakin masif sebagai sebuah proses transformasi sosial menuju masyarakat dan desa pengguna teknologi digital akan semakin penting masa mendatang.

Satu pemikiran yang dibangkitkan dari konsep sodality adalah kepemimpinan yang mengenal dan dikenal pengikutnya (rakyat). Dengan demikian, kepemimpinan digital menjadi sebuah keperluan strategis untuk ditelaah maupun diinternalisasikan dalam tranformasi digital. Proses yang diarahkan dapat mewujudkan masyarakat dan desa yang dikenal cerdas (smart) didasari tidak hanya oleh warga pandai, tetapi juga didukung oleh mereka yang kreatif. 


\section{Pemikiran S.M.P Tjondronegoro sebagai Landasan Kurikulum SPD}

Uraian sebelumnya menjadi landasan pembahasan tentang pemikiran dari Almarhum Prof. Dr. S.M.P. Tjondronegoro dalam perkembangan dan pengembangan Prodi Sosiologi Pedesaan. Sebagaimana dicatat Sosiologi Pedesaan mulai diperkenalkan di Indonesia oleh Prof. Dr. Sajogyo pada tahun 1959 di Fakultas Pertanian yang masih menjadi bagian dari Universitas Indonesia. Setelah menjadi Institut Pertanian Bogor (IPB) dikembangkan menjadi Sosiologi Pedesaan dengan embrio dua mata kuliah dari gugus sosial-ekonomi yaitu ekonomi pertanian dan sosiologi pertanian yang diajarkan kepada mahasiswa tingkat pertama di IPB. Dalam usaha yang dilakukan Prof. Dr. Sajogyo untuk memperkenalkan Sosiologi Pedesaan banyak merujuk berbagai pemikiran ilmuan lain seperti DH. Penny (masalah pertanian Sumatera Utara), AT. Mosher yang merupakan ahli di bidang ekonomi pertanian yang lama mengajar di negara-negara berkembangan, seperti India. Timmer yang menjadi perintis penggunaan istilah agronomi sosial. Selain itu, Gouldner seorang sosiolog yang membedakan antara clinical sociology dan engenering. Dengan demikian, Sosiologi Pedesaan dengan ciri yang khas sebagai ilmu sosial. Sebagai ilmu dikembangkan berdasarkan penjelasan atas fakta-fakta sosial baik perilaku individu maupun kelompok dan dipertautkan dengan praktik berteori sebagai kenyataan. Sebagaimana disebutkan sebelumnya, Sosiologi Pedesaan yang berkembang di IPB kuat dari segi empirisme.

Dari catatan sejarah, pada tahun 1975 bersamaan dengan pendirian pertama program pendidikan pascasarjana, baik di IPB maupun di Indonesia, Sosiologi Pedesaan menjadi salah satu program pendidikan di aras pascasarjana. Program Pendidikan Pascasarjana Sosiologi Pedesaan pada tahap awal ini diampu oleh Prof. Dr Sajogyo dan 3 orang dosen lain, yaitu Prof. Dr. Selo Sumardjan, Prof. Dr. S.M.P. Tjondronegoro dan Prof. Dr. Pujiwati Sajogyo. Di era awal pendiriannya, Pendidikan Sosiologi Pedesaan memuat Mata Kuliah (MK), seperti: Struktur Sosial dan Organisasi, Kependudukan, Ekologi Manusia, Perubahan Sosial, Dinamika Masyarakat dan Dinamika Pedesaan. Empat dari lima MK yang disebut terakhir, kemudian diampu dan dikembangkan oleh Prof. Dr. S.M.P. Tjondronegoro. MK hingga Tahun 2006 yang berkembang dalam kurikulum adalah Struktur \& Organisasi Sosial, Sistem Hukum Pedesaan, Kependudukan, Ekologi Manusia, Psikologi Sosial (dalam konteks Petani dan Warga Desa), Sosiologi Pembangunan, Dinamika Masyarakat Pedesaan, Sejarah Politik Pedesaan, Sosiologi Agraria, dan Perubahan Sosial. Lihat Gambar 2.

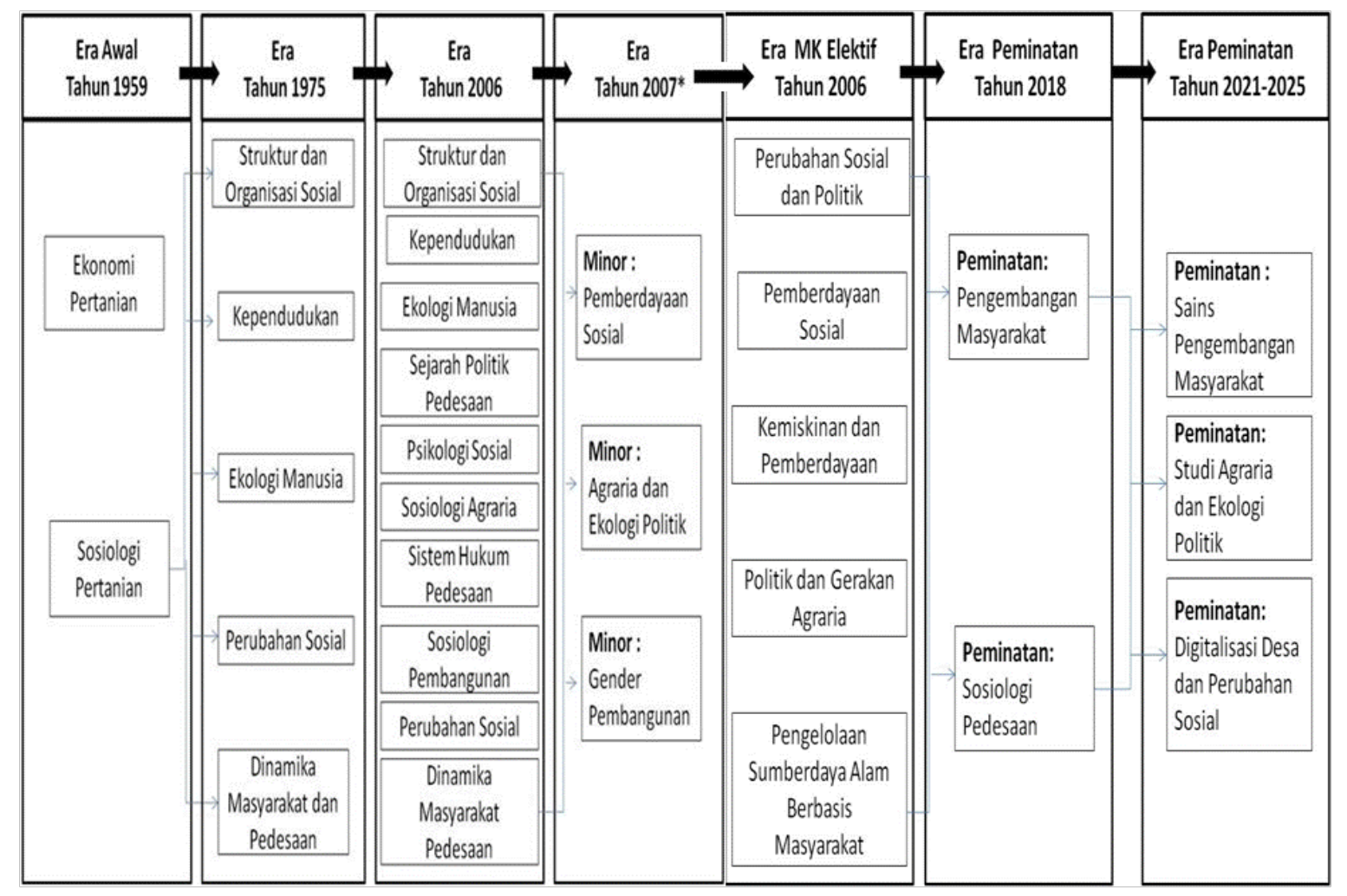

Keterangan : * Era Program Mayor/Minor yang digagas dan dilaksanakan oleh IPB

Gambar 2. Peta Perkembangan Pendidikan Sosiologi Pedesaan 
Perkembangan Program Pendidikan Pasca Sosiologi Pedesaan tidak terlepas dari berbagai kritik. Baik, yang datang dari pihak luar maupun oto-kritik dari kalangan sendiri. Salah satu kritik dari luar adalah dari Benyamin White, yang menyebutkan, bahwa ilmu sosial di Indonesia mengalami ketertinggalan akibat pengembangan keilmuan bersifat apologia yang membenarkan kondisi masyarakat menurut kebijakan pemerintah (Orde Baru). Menurut (Zainuddin, 2009), secara khusus kritik pada penelitian dalam kaitan pengembangan pendidikan Sosiologi Pedesaan IPB adalah kurang menyoroti dan mendalami transformasi agraria. Merespon kritik tersebut, Program pendidikan Sosiologi Pedesaan memfokuskan pada tiga gugus kajian, yaitu: (1) Transisi agrarian yang berorientasi pada pemerataan peluang usaha, peluang kerja dan pemerataan penghasilan; (2) Transformasi Tata kelola kebijakan dalam beragam jenis lembaga/organisasi masyarakat; (3) Kependudukan dan kehidupan sosial yang berorientasi ekologis pedesaan.

Oto-kritik yang ada terhadap Program Pendidikan Sosiologi Pedesaan adalah kecenderung alumni menjadi peneliti atau dosen di kampus. Padahal, ketika Gerakan Reformasi yang terwujud pada Tahun 1998 terjadi perubahan orientasi pembangunan dari bercorak sentralisasi ke desentralisasi. Pemerintah daerah memerlukan penggerak-penggerak pembangunan dengan ciri mampu berpraktek yang berteori. Melalui inisiatif Dr. Felix Sitorus, lahirlah Program Pendidikan Pascasarjana yang baru bernama Manajemen Pengembangan Masyarakat pada Tahun 2002. Program yang mendapat apresiasi dari pemerintah (Kementerian Dalam Negeri RI) yang kemudian dengan bantuan Asia Development Bank, program ini dikembangkan untuk memperkuat aparatur pemerintah. Apresiasi juga diperoleh dari Kementerian Sosial RI, yang kemudian mengembangkan program pendidikan pascasarjana dengan Sekolah Tinggi Kesejahteraan Sosial, dan meluluskan alumni dengan kompetensi penggerak sosial melalui komunitas yang tersebar di seluruh Indonesia. Dukungan kehadiran program hasil otokritik ini diapresiasi juga oleh beberapa pemerintah daerah melalui program penguatan sumberdaya manusia, seperti Pemerintah Kabupaten Bengkalis di Provinsi Riau, Kabupaten Sumbawa Barat di Nusatenggara Barat. Penting dicatat, dalam penyelenggaraan pendidikan di Kabupaten Sumbawa Barat didukung oleh Korporasi Multi-Nasional. Bahkan, sistemnya sudah menggunakan dual-mode, dengan online yang dikuatkan oleh offline. Program ini pun hingga Tahun 2021 dikategori akreditasi Sangat Baik (Akreditasi A) dari Badan Akreditasi Nasional RI.

Dalam kaitan pengembangan kurikulum program mayor-minor di IPB, pada Tahun 2007 Program Mayor/Minor Sosiologi Pedesaan membentuk tiga minor, yaitu: (1) Minor Pemberdayaan Sosial, (2) Minor Agraria dan Ekologi Politik, dan (3) Minor Gender Pembangunan (Lihat kembali Gambar 2).

Pada tahun 2009-2011 Sosiologi Pedesaan IPB membentuk beberapa mata kuliah elektif (pilihan) yang dapat diambil oleh setiap mahasiswa pascasarjana sesuai dengan peminatan dan kebutuhan keilmuan untuk penelitian yang akan dilakukannya. Beberapa mata kuliah elektif itu, yaitu: Perubahan Sosial dan Politik Pemberdayaan; Sosiologi Kemiskinan dan Pemberdayaan; Politik dan Gerakan Sosial; dan Pengelolaan Sumberdaya Alam Berbasis Masyarakat.

Pada tahun 2018, karena desakan "pengaturan" Sosiologi Pedesaan diminta kembali menjadi rumah Program Studi Manajemen Pengembangan Masyarakat. Dengan catatan, Program Studi Manajemen Pengembangan Masyarakat disiapkan sebagai program studi vokasi di aras pascasarjana dengan nama Program Studi Pengembangan Masyarakat. Dan, pendidikan pascasarjana Pengembangan Masyarakat menjadi satu peminat Sosiologi Pedesaan dengan nama Pemintan Sains Pengembangan Masyarakat.

Pada tahun 2019 Program Studi Sosiologi Pedesaan mengenal dua peminatan, yaitu: (1) Sosiologi Pedesaan dan (2) Pengembangan Masyarakat. Dengan sistem peminatan ini ada mata kuliah spesifik yang diajarkan di masing-masing peminatan. Peminatan Sosiologi Pedesaan diajarkan 4 mata kuliah yaitu: Sosiologi Ekonomi Pedesaan; Ekologi Politik; Transformasi dan Gerakan Agraria; dan Sosiologi Komunitas. Sementara peminatan Pengembangan Masyarakat diajarkan 4 mata kuliah, yaitu: Analisis dan Kebijakan Sosial; Tata Kelola Pengembangan Masyarakat; Sosiologi Digital Pengembangan Masyarakat; dan Relasi Komunitas Pedesaan dan Perkotaan.

Program Studi Sosiologi Pedesaan kemudian memandang penting terus mengembangkan peminatan yang dipilih secara sukarela oleh mahasiswa. Dalam kurikulum Periode 2021-2025, peminatan di program ini menjadi tiga, yaitu: (1) Sains Pengembangan Masyarakat, (2) Studi Agraria dan Ekologi Politik, dan (3) Digitalisasi Desa dan Perubahan Sosial. Dari Gambar 2 juga, dapat dilihat perkembangan kurikulum tidak lepas dari tapak pemikiran dan pengembangan pemikiran Prof. Dr. S.M.P Tjondronegoro. Dengan garis, dari MK menjadi Kumpulan MK dalam sebuah peminatan yang 
memberi fokus konsentrasi keilmuan dari mereka yang mempelajari Sosiologi Pedesaan. Peminatan ini juga sebagai bagian dari merespon perkembangan abad digital terutama merespon gagasan dalam mewujudkan Revolusi Industri 4.0 yang menguatkan transformasi digital yang mewujudkan Masyarakat Cerdas (Smart Society) 5.0 di Indonesia. Susunan lengkap kurikulum Program Studi Sosiologi Pedesaan Tahun 2021-2025 dapat dilihat pada Tabel 1 dan 2.

Tabel 1. Komponen Mata Kuliah Prodi Sosiologi Pedesaan (Program Master) dalam Kurikulum Periode 2021-2025

\begin{tabular}{|l|c|}
\hline \multicolumn{1}{|c|}{ Rekapitulasi Komponen Matakuliah } & Jumlah SKS \\
\hline Common Course/MK Wajib Program Pascasarjana (CC) & 3 \\
\hline Foundational Course/MK Dasar Pilar Prodi (FC) & 8 \\
\hline Academic Core Course/MK Wajib Prodi (ACC) & 9 \\
\hline In-depth Course/MK Wajib Peminatan (IC) & 14 \\
\hline Enrichment Course/ MK Pengayaan dari Luar Prodi* & 39 \\
\hline Tugas Akhir (TA) & 3 \\
\hline Total SKS Wajib & \\
\hline
\end{tabular}

*EC diambil dari Matakuliah Seminar Hasil senilai 1 sks

\begin{tabular}{|c|c|c|c|c|}
\hline \multirow{2}{*}{ Kode } & \multirow{2}{*}{ Nama } & \multirow{2}{*}{ Kredit } & \multicolumn{2}{|c|}{ Semester } \\
\hline & & & Ganjil & Genap \\
\hline \multicolumn{5}{|c|}{ Daftar Mata Kuliah Wajib SPs (Common Course) (3 sks) } \\
\hline PPS503 & Bahasa Inggris & $3(3-0)$ & Ganjil & Genap \\
\hline KPM53C & Metodologi Penelitian Sosiologi Pedesaan & $3(3-0)$ & & II \\
\hline \multicolumn{5}{|c|}{ Daftar Matakuliah Wajib Prodi (Foundational Course ) (5 sks) } \\
\hline KPM633 & $\begin{array}{l}\text { Teori-teori Sosiologi Pedesaan dan Pengembangan } \\
\text { Masyarakat }\end{array}$ & $3(3-0)$ & I & \\
\hline KPM50H & Metode Kuantitatif untuk Ilmu Sosial & $2(2-0)$ & I & \\
\hline \multicolumn{5}{|c|}{ Daftar Matakuliah Wajib Prodi (Academic Core Course) (8 sks) } \\
\hline KPM50I & Komunitas, Desa, Gender dan Inklusi Sosial & $3(3-0)$ & I & \\
\hline KPM563 & Kependudukan dan Ekologi Manusia & $3(2-1)$ & I & \\
\hline KPM53D & Sains, Teknologi, dan Perubahan Sosial & $2(2-0)$ & I & \\
\hline \multicolumn{5}{|c|}{ Daftar Matakuliah Wajib Peminatan (In-Depth Course) (9 sks) } \\
\hline \multicolumn{2}{|c|}{ Peminatan Digitalisasi Desa dan Perubahan Sosial } & & & \\
\hline KPM53E & Sosiologi Digital & $3(3-0)$ & & II \\
\hline KPM53F & $\begin{array}{l}\text { Data Presisi, Ekonomi-Politik dan Kebudayaan } \\
\text { Digital* }\end{array}$ & $3(2-1)$ & & II \\
\hline KPM53G & $\begin{array}{l}\text { Analisis dan Solusi Masalah Sosial Teknologi } \\
\text { Digital* }\end{array}$ & $3(2-1)$ & & II \\
\hline \multicolumn{2}{|c|}{ Peminatan Sains Pengembangan Masyarakat } & & & \\
\hline KPM531 & Sosiologi Ekonomi Pedesaan** & $2(2-0)$ & & II \\
\hline
\end{tabular}




\begin{tabular}{|c|c|c|c|c|}
\hline \multirow{2}{*}{ Kode } & \multirow{2}{*}{ Nama } & \multirow{2}{*}{ Kredit } & \multicolumn{2}{|c|}{ Semester } \\
\hline & & & Ganjil & Genap \\
\hline KPM572 & Analisis dan Kebijakan Sosial* & $2(2-0)$ & & II \\
\hline KPM573 & Tata Kelola Pengembangan Masyarakat & $3(2-1)$ & & II \\
\hline KPM574 & Sosiologi Komunitas Digital $* *$ & $2(2-0)$ & & II \\
\hline KPM575 & Relasi Komunitas Perdesaan dan Perkotaan & $2(2-0)$ & & II \\
\hline \multicolumn{5}{|c|}{ Peminatan Studi Agraria dan Ekologi Politik } \\
\hline KPM560 & Ekologi Politik* & $3(3-0)$ & & II \\
\hline KPM564 & Transformasi dan Gerakan Agraria-Lingkungan & $3(3-0)$ & & II \\
\hline KPM565 & $\begin{array}{l}\text { Tata Kelola Agraria-Lingkungan dan Pembangunan } \\
\text { Berkelanjutan* }\end{array}$ & $3(3-0)$ & & II \\
\hline \multicolumn{5}{|c|}{ Daftar Tugas Akhir (14 sks) } \\
\hline KPM60B & Kolokium & $1(0-1)$ & III & \\
\hline KPM60A & Proposal Tesis & $2(0-2)$ & III & \\
\hline PPS692 & Publikasi Ilmiah Nasional & $2(0-2)$ & III & \\
\hline PPS691 & Seminar Tesis $* * *$ & $1(0-1)$ & Ganjil & Genap \\
\hline KPM60E & Ujian Tesis & $2(0-2)$ & & IV \\
\hline KPM60G & Tesis & $6(0-6)$ & & IV \\
\hline & \multicolumn{4}{|c|}{ TOTAL SKS 39 sks } \\
\hline
\end{tabular}

* Dapat diganti dengan mata kuliah dari luar prodi (prodi lain di IPB, luar IPB atau luar negeri) atas persetujuan Ketua Komisi Pembimbing dan Kaprodi

**Dipilih salah satu sebagai mata kuliah In-depth pilihan pada peminatan Sains Pengembangan Masyarakat sesuai dengan topik tesis

*** Enrichment Course

Tabel 2. Komponen Mata Kuliah Prodi Sosiologi Pedesaan (Program Doktor Reguler dan Berdasarkan Penelitian) dalam Kurikulum Periode 2021-2025

\section{Program Reguler}

\begin{tabular}{|l|c|}
\hline \multicolumn{1}{|c|}{ Rekapitulasi Komponen Matakuliah (Doktor Reguler) } & Jumlah SKS \\
\hline Common Course/MK Wajib Program Pascasarjana (CC) & 2 \\
\hline Foundational Course/MK Dasar Pilar Prodi (FC) & 2 \\
\hline Academic Core Course/MK Wajib Prodi (ACC) & 6 \\
\hline In-depth Course/MK Wajib Peminatan (IC) & 28 \\
\hline Enrichment Course/ MK Pengayaan dari Luar Prodi* & 45 \\
\hline Tugas Akhir (TA) & \\
\hline Total SKS Wajib & \\
\hline
\end{tabular}

*EC diambil dari Matakuliah Seminar Hasil senilai 1 sks 


\begin{tabular}{|c|c|c|c|}
\hline Kode & Nama & Kredit & Semester \\
\hline \multicolumn{4}{|c|}{ Daftar Mata Kuliah Wajib SPs (Common Course) (3 sks) } \\
\hline PPS503 & Bahasa Inggris & $3(3-0)$ & Ganjil/Genap \\
\hline PPS704 & Filsafat Sains & $2(2-0)$ & Ganjil \\
\hline \multicolumn{4}{|c|}{ Daftar Matakuliah Wajib Prodi (Foundational Course ) (7 sks) } \\
\hline KPM602 & Epistema/(Peta) Filsafat Ilmu Sosial & $2(2-0)$ & I \\
\hline KPM633 & $\begin{array}{l}\text { Teori-Teori Sosiologi Pedesaan dan Pengembangan } \\
\text { Masyarakat }\end{array}$ & $3(3-0)$ & I \\
\hline KPM739 & Metodologi Penelitian Sosiologi Pedesaan Lanjut & $2(2-0)$ & I \\
\hline \multicolumn{4}{|c|}{ Daftar Matakuliah Wajib Prodi (Academic Core Course) (2 sks) } \\
\hline KPM730 & $\begin{array}{l}\text { Dinamika Struktur Sosial dan Kebudayaan } \\
\text { Masyarakat Pedesaan }\end{array}$ & $2(2-0)$ & I \\
\hline \multicolumn{4}{|c|}{ Daftar Matakuliah Wajib Reguler (In-Depth Course) (6 sks) } \\
\hline KPM731 & Dinamika Ekonomi Pedesaan & $2(2-0)$ & II \\
\hline KPM761 & Dinamika Kependudukan & $2(2-0)$ & II \\
\hline KPM724 & Politik Agraria* & $2(2-0)$ & II \\
\hline KPM73A & Sosiologi Digital untuk Pengembangan Masyarakat* & $2(2-0)$ & II \\
\hline KPM760 & Teori Sosial Hijau* & $2(2-0)$ & II \\
\hline KPM73B & Investasi Sosial dan Pengembangan Masyarakat* & $2(2-0)$ & II \\
\hline KPM70J & Gender dan Dinamika Masyarakat* & $2(2-0)$ & II \\
\hline KPM70K & Keluarga dan Komunitas Pedesaan* & $2(2-0)$ & II \\
\hline \multicolumn{4}{|c|}{ Daftar Tugas Akhir (28 sks) } \\
\hline KPM70B & Ujian Kualifikasi Tertulis & $2(0-2)$ & III \\
\hline KPM70C & Ujian Kualifikasi Lisan & $2(0-2)$ & III \\
\hline KPM70D & Kolokium & $1(0-1)$ & III \\
\hline KPM70N & Proposal Disertasi & $2(0-2)$ & IV \\
\hline PPS791 & Seminar Disertasi** & $1(0-1)$ & Ganjil/Genap \\
\hline PPS792 & Publikasi Ilmiah Nasional & $2(0-2)$ & IV \\
\hline PPS793 & Publikasi Ilmiah Internasional & $3(0-3)$ & IV \\
\hline KPM70O & Ujian Tertutup & $3(0-4)$ & IV \\
\hline KPM70P & Disertasi & $12(0-12)$ & IV \\
\hline
\end{tabular}

* Matakuliah wajib yang hanya dipilih satu dari berbagai pilihan sesuai dengan tema penelitian, dan dapat diganti dengan mata kuliah dari luar prodi (prodi lain di IPB, luar IPB atau luar negeri) atas persetujuan Ketua Komisi Pembimbing dan Kaprodi.

** Enrichment Course

\section{Program Berdasarkan Penelitian}

\begin{tabular}{|l|c|}
\hline \multicolumn{1}{|c|}{ Komponen Matakuliah Doktor Berdasarkan Penelitian } & Jumlah SKS \\
\hline Common Course/MK Wajib Program Pascasarjana (CC) & 2 \\
\hline Foundational Course/MK Dasar Pilar Prodi (FC) & 3 \\
\hline Academic Core Course/MK Wajib Prodi (ACC) & 6 \\
\hline In-depth Course/MK Wajib Peminatan (IC) & 31 \\
\hline Enrichment Course/ MK Pengayaan dari Luar Prodi* & 44 \\
\hline Tugas Akhir (TA) & 4 \\
\hline Total SKS Wajib & \\
\hline
\end{tabular}


*EC diambil dari Matakuliah Seminar Hasil senilai 1 sks

\begin{tabular}{|c|c|c|c|}
\hline Kode & Nama & Kredit & Semester \\
\hline \multicolumn{4}{|c|}{ Daftar Mata Kuliah Wajib SPs (Common Course) (3 sks) } \\
\hline PPS503 & Bahasa Inggris & $3(3-0)$ & $\begin{array}{c}\text { Ganjil/ } \\
\text { Gena } \\
\text { p }\end{array}$ \\
\hline PPS704 & Filsafat Sains & $2(2-0)$ & Ganjil \\
\hline \multicolumn{4}{|c|}{ Daftar Matakuliah Wajib Prodi (Foundational Course ) (7 sks) } \\
\hline KPM633 & $\begin{array}{l}\text { Teori-Teori Sosiologi Pedesaan dan Pengembangan } \\
\text { Masyarakat }\end{array}$ & $3(3-0)$ & I \\
\hline \multicolumn{4}{|c|}{ Daftar Matakuliah Wajib Prodi (Academic Core Course) (2 sks) } \\
\hline KPM730 & $\begin{array}{l}\text { Dinamika Struktur Sosial dan Kebudayaan } \\
\text { Masyarakat Pedesaan }\end{array}$ & $2(2-0)$ & I \\
\hline \multicolumn{4}{|c|}{ Daftar Matakuliah Wajib by Research (In-Depth Course) (6 sks) } \\
\hline KPM70L & Topik Khusus $1^{*}$ & $3(3-0)$ & I \\
\hline KPM70M & Topik Khusus $2 *$ & $3(3-0)$ & II \\
\hline \multicolumn{4}{|c|}{ Daftar Tugas Akhir (31 sks) } \\
\hline KPM70B & Ujian Kualifikasi Tertulis & $2(0-2)$ & II \\
\hline KPM70C & Ujian Kualifikasi Lisan & $2(0-2)$ & II \\
\hline KPM70D & Kolokium & $1(0-1)$ & II \\
\hline KPM70N & Proposal Disertasi & $2(0-2)$ & II \\
\hline PPS791 & Seminar Disertasi** & $1(0-1)$ & IV \\
\hline PPS792 & Publikasi Ilmiah Nasional & $2(0-2)$ & IV \\
\hline PPS794 & Publikasi Ilmiah Internasional 1 & $3(0-3)$ & $\mathrm{V}$ \\
\hline PPS795 & Publikasi Ilmiah Internasional 2 & $3(0-3)$ & $\mathrm{V}$ \\
\hline KPM70O & Ujian Tertutup & $3(0-3)$ & $\mathrm{V}$ \\
\hline KPM70P & Disertasi & $12(0-12)$ & $\mathrm{V} / \mathrm{VI}$ \\
\hline \multicolumn{4}{|c|}{ TOTAL SKS 44 sks } \\
\hline
\end{tabular}

* Topik Khusus akan ditentukan oleh Promotor dan anggota komisi pembimbing

** Enrichment Course

\section{KESIMPULAN}

Gagasan dan pemikiran Almarhum Prof. Dr. S.M.P. Tjondronegoro yang dikenal sebagai konsep sodality banyak memiliki keterhubungan dengan kehadiran Undang-undang Nomor 6 Tahun 2014 tentang Desa. Temuan konsep sodality oleh Almarhum Prof. Dr. S.M.P. Tjondronegoro menunjukkan, bahwa penetrasi pengaruh supra desa kepada desa mengakibatkan keretakan orientasi kepentingan antara sepertiga lapisan atas dan dua pertiga lapisan lainnya, dapat dijembati oleh sodality sebagai masyarakat dalam skala kecil. Oleh karena di aras sodality masih ditemukan kesamaan orientasi kepentingan antara pemimpin dan pengikut. Hal yang dapat mendasari mengembangkan tata kelola pembangunan desa yang tertuang dalam Undang-undang tentang Desa. Dengan pendekatan "Desa Membangun", sodality dapat menjadi ruang partisipasi warga desa untuk ikut mengelola pembangunan. Terkait dengan hal tersebut, kajian tentang sodality juga dapat menjawab kemandekan atas implementasi percepatan "Membangun Desa" melalui kerjasama antar desa dalam kawasan perdesaan. Kepemimpinan dari tokoh di aras sodality ini dapat membuka satuan-satuan organisasi di desa untuk berkolaborasi dengan berbagai pihak mengelola pembangunan kawasan perdesaan. 
Almarhum Prof. Dr. S.M.P. Tjondronegoro juga menempatkan perhatian besar pada peranan teknologi sebagai sumber transformasi masyarakat termasuk perkembangan masyarakat di era digital. Pemikiran yang sejalan dengan konsep sodality ini dan kaitannya dengan era digital yaitu menempatkan faktor kepemimpinan digital menjadi sebuah keperluan strategis untuk ditelaah maupun diinternalisasikan dalam transformasi digital. Konsep sodality dapat terus digunakan sebagai fondasi kuat bagi ilmu pengetahuan khususnya Sosiologi Pedesaan untuk merespon perkembangan abad digital terutama gagasan dalam mewujudkan Revolusi Industri 4.0 yang menguatkan transformasi digital yang mewujudkan Masyarakat Cerdas (Smart Society) 5.0 di Indonesia.

Berdasarkan hasil penelaah yang telah diuraikan ditunjukkan, bahwa pengembangan kurikulum pendidikan Sosiologi Pedesaan memang berakar, tumbuh, berkembang, dan dikembangkan dari pemikiran Almarhum Prof.Dr S.M.P Tjondronegoro. Kurikulum tersebut juga terus dikemas untuk merespon dinamika kehidupan desa dan upaya membangun kerjasama antar desa lebih produktif dalam memberi peningkatan taraf hidup warga desa. Hal lain, yang perlu dicatat adalah penyusunan kurikulum tersebut sebagai proses. Kegiatannya dilakukan secara inklusif melibatkan berbagai pihak berkepentingan (seperti alumni dan mahasiswa, pengajar/dosen, pengguna dari berbagai kalangan/lembaga pemerintahan, lembaga swadaya masyarakat dan korporasi, komunitas warga desa, penggerak media baik offline maupun online). Sebagai proses, kegiatan tersebut pun dilakukan dalam waktu yang tidak singkat. Melalui seri lokakarya yang diselenggarakan secara bertahap dengan frekuensi lebih dari satu kali, baik secara offline maupun online.

\section{UCAPAN TERIMA KASIH}

Ucapan terima kasih disampaikan kepada pengelola Program Studi Pascasarjana Sosiologi Pedesaan atas bantuan penyediaan data dan informasi. Kami juga mengucapkan terima kasih kepada alumni, dosen dari Prodi Sosiologi Pedesaan sebagai informan yang banyak memberi bahan dan sudut pandangan pemikiran, sehingga tulisan ini dapat diselesaikan.

\section{DAFTAR PUSTAKA}

Beer, R. B. and D. (2013). Rethinking Space: Urban Informatics and the Sociological Imagination. In The Palgrave Macmillan Digital Sociology (Kate Orton). Palgrave Macmillan.

Castells, M. (2010). The Rise of the Network Society Second edition. Wiley Blackwell Publication.

Deborah Lupton. (2015). Digital Sociology. Routledge.

Evans, K. (2013). Rethinking Community in the Digital Age? In The Palgrave Macmillan Digital Sociology. Palgrave Macmillan.

Farid, H. (2014). Rewriting the Nation: Pramoedya Ananta Toer and the Politics of Decolonization Disertasi Ph.D. National University of Singapore.

Farid, H. (2017). Agenda Dekolonisasi Kebudayaan Nasional dalam Perspektif Ki Hadjar Dewantara. Abad Jurnal Sejarah, 1(1).

Fontaine, M. R. and D. (2018). Sustainable Community Development and the Green Economy: Ensuring a Strong Sustainability Approach. In B. M. and R. P. (Ed) Sue Kenny (Ed.), The Routledge handbook of community development : perspectives from around the globe. Routledge.

Inet.detik.com. (2020). Riset: Ada 175,2 Juta Pengguna Internet di Indonesia. https://inet.detik.com/cyberlife/d-4907674/riset-ada-1752-juta-pengguna-internet-di-indonesia

Jan A.G.M.van Dijk. (2013). Inequalities in the Network Society. In The Palgrave Macmillan Digital Sociology. Palgrave Macmillan.

Kelly Hamshaw, Shoshanah Inwood, J. K. and M. N. (2018). The Role of Community Engagement and Indicators Generating Knowledge for Informing Regional Planning for Sustainability. In The Routledge handbook of community development : perspectives from around the globe. Routledge. 
Kitchenham, B. (2004). Procedures for Performing Systematic Reviews. Keele University.

Kolopaking, L, M. (2008). Kecamatan Untuk Kesejahteraan Rakyat. Departemen Sains Komunikasi Pengembangan Masyarakat Press.

Kolopaking, L, M. (2014). Kebijakan Ruang Membangun Kawasan Perdesaan Partisipatif.

Kolopaking, L, M. (2017). Village to develop and to Develop cooperation among villages sustainable in digital era for Strethening Village Competitiveness. "Policy Intervention of Development Village Competiveness."

Kolopaking, L, M. (2020). Pembelajaran tentang Tata-kelola Alih Teknologi dan Pembiayaan Pedesaan Pada Era Digital.

Maschab, M. (2013). Politik Pemerintahan Desa di Indonesia. Pusat Antar Universitas UGM.

Mosco, V. (2017). Society Now Becoming Digital Toward a Post-Internet Society. Emerald Publishing Limited.

Prior, K. O.-J. and N. (2013). The Palgrave Macmillan Digital Sociology. Palgrave Macmillan.

Rhode, R. A. . (2014). Network Governance and the Differentiated Polity Selected Essays, Volume I. McGrow-Hill.

Sajogyo. (2004). Dari Praktek ke Teori dan Ke Praktek yang Berteori.

Satria, A. (2021). Modernisasi Ekologi dan Ekologi Politik: Perspektif Baru Analisis Tata Kelola Sumber Daya Alam (SDA). Orasi Guru Besar Institut Pertanian Bogor.

Schwab, K. (2016). The Fourth Industrial Revolution. World Economic Forum.

Singleton, E. G. and C. (2013). 'Gendering the Digital': The Impact of Gender and Technology Perspectives on the Sociology Imagination. In The Palgrave Macmillan Digital Sociology. Palgrave Macmillan.

Tjondronegoro, S. M. . (1979). Tata Desa dan Kelembagaan dalam Pembangunan Daerah Pedesaan. Pusat Penelitian dan Pengembangan Departemen Dalam Negeri RI.

Tjondronegoro, S. M. . (1984). Social Organizatiom and Planned Development in Rural Java. Oxford University Press.

Tjondronegoro, S. M. . (1986a). Masalah Transformasi Indonesia dari Tahap Agraris ke Era Industrialisasi. Lembaga Penelitian Sosiologi Pedesaan.

Tjondronegoro, S. M. . (1986b). Menghadapi Alih Teknologi di bidang Pangan Menjelang Repelita V. Dalam Fauzan Djamal dan Sofwan Samandawai (Penyunting). In Negara Agraris Ingkari Agraria: Pembangunan Desa dan Kemiskinan di Indonesia. AKATIGAS.

Tjondronegoro, S. M. . (1990). Kemiskinan dan Kesenjangan di Tengah Pertumbuhan 1990. Jurusan Sosial Ekonomi Fakultas Pertanian IPB.

Tjondronegoro, S. M. . (1996). Suasana Keprihatinan Mengiringi Masyarakat Kita Memasuki Era Globalisasi. Panel Ekonomi KOMPAS.

Tjondronegoro, S. M. . (2005). Rural Development and Rural Poverty Reduction : Promises Between Fisrt UN Development Decade and Millenium Development Goal 1960-2005. UN ESCAPE.

Zainuddin, S. (2009). Sosiologi Pedesaan Sebagai Ilmu Pengetahuan. Academia FISIP Untad, 1. https://media.neliti.com/media/publications/28563-ID-sosiologi-pedesaan-sebagai-ilmupengetahuan.pdf 